\title{
THE INFLUENCE OF PERCEPTION AND ATTITUDE TOWARDS THE CUSTOMER BEHAVIOUR IN USING SHARIA BANKING FINANCIAL SERVICES IN MEDAN
}

\author{
Muhammad Fauzan Azhmy ${ }^{1}$ \\ ${ }^{1}$ Program Studi Magister Manajemen Fakultas Ekonomi dan Bisnis Universitas Harapan Medan, Jl. \\ Imam Bonjol No. 35 Medan - Sumatera Utara, Telp.061-4514560, e-mail : unhar@harapan.ac.id
}

\begin{abstract}
The formation of perception will have an impact on the progress of Bank Syariah will also encourage people to be able to use the services of Bank Syariah as financial institutions. Lack of understanding and lack of education that they get gives different perceptions about Bank Syariah products, this is not in accordance with the real reality that Bank Syariah are banks that adopt Islamic Sharia values that forbid interest. Customer perception is closely related to attitude so that what is done by the customer is an objective reality that will influence their behaviour to use Bank Syariah services. The purpose of this study was to determine whether perceptions and attitudes affect the behaviour of entrepreneurs and employees in using sharia banking financial services. The sampling technique uses quota sampling. To conduct data analysis, data processing is carried out by using path analysis. The results of this study stated that partially perception variables significantly influence to the behaviour variables and attitude variables significantly influence to behaviour variables.
\end{abstract}

Key words: perception, attitude, customer behaviour.

Muhammad Fauzan Azhmy. 2020. The Influence of Perception and Attitude Towards the Customer Behaviour in Using Sharia Banking Financial Services in Medan. Jurnal Nisbah 6 (2): 99-107

\section{INTRODUCTION}

One that affects the development of Bank Syariah by improving service strategies to customers or prospective customers. The strategy to do the best service becomes an option when Bank Syariah want to grow and grow from year to year the number of customers. Bank Syariah, which are business institutions, are not humanitarian institutions that insist on having to provide the best for customers and the public that will be customers by providing some of the best knowledge and offers that can be given. The formation of perception will have an impact on the progress of Bank Syariah will also encourage people to be able to use the services of Bank Syariah as financial institutions.

Perception is felt very important, because perception is a process when individuals organize and interpret their sensory impressions to give meaning to their environment. However, if Bank Syariah are considered to be like banks in general, this is inseparable from the lack of understanding from the public and the lack of education carried out by Bank Syariah regarding this new concept which is applied in the banking world. Lack of understanding and lack of education that they get gives different perceptions about Islamic bank products, this is not in accordance with the real reality that Islamic banks are banks that adopt Islamic sharia values that forbid interest.

The respondents' attitudes toward interest and profit sharing are very diverse, some people still receive interest, some receive profit sharing systems while still receiving interest, and some reject interest so that these various attitudes provide quite interesting nuances as a description of people's perceptions, attitudes and behaviour in responding to Islamic banking. This phenomenon is to be 
investigated, because it is undeniable that Bank Syariah are business institutions, willing or not must provide more value to their products, one of which is the return value that consumers or customers get after saving or borrowing money in Bank Syariah. While Bank Syariah with a profitsharing system do not provide certainty of income as conventional bank interest provides certainty of income. As a result of such perceptions that ultimately affect the attitudes and behaviour of prospective customers, especially entrepreneurs and employees in using financial services in Bank Syariah.

\section{THEORY AND METHODE}

\section{Behaviour}

Behaviour in a large Indonesian dictionary is a person's response to the environment or events related to individuals. According to Schiffman and Kanuk (2008: 5) studies of the consumer behaviour centred on the way of individuals make decisions to utilize their available resources (time, money, effort) to buy goods or services related to consumption. Being according to Prasetijo and Ihalauw (2005: 8) is the consumer behaviour can be interpreted as a study of how decision makers (decision units), both individuals, groups, or organizations, make purchasing decisions or make a purchase transaction of a product and consume it. In addition, consumer behaviour is the things that underlie consumers to make purchasing decisions.

Prasetijo and Ihalauw (2005: 5) concluded that consumer behaviour is a process that consists of several stages:

1. Acquisition stage (acquisition): searching (searching) and buying (purchasing).

2. Consumption stage (consumption): using and evaluating.

3. Post-purchase action stage (disposition): what consumers do after the product is used or consumed.

\section{Attitude}

Attitudes explain cognitive evaluation, emotional feelings and the tendency of actions of someone who likes or dislikes certain objects or ideas. People have attitudes to almost everything: religion, politics, clothing, music, food and so on. Attitude puts a person into a frame of mind about educating or disliking an object (Philip Kothler, 2000: 245).

Attitude is something that determines the attitude of nature, nature, both current and future acts. Each attitude has three aspects namely (Ahmadi, 2002: 162):

a. Cognitive aspects

That is related to the symptoms of knowing the mind. This means tangible processing, experience and beliefs and individual expectations about a particular object or group of objects.

b. Affective aspects

Manifest process that involves certain feelings such as fear, malice, sympathy, antipathy and so on aimed at certain objects.

c. Conative aspect

Tangible process of tendency/ tendency to do something object.

Attitudes are evaluations, feelings and tendencies of a person that are relatively consistent with an object or idea. Attitude puts a person into a mind like or not educate something, move toward or away from something (Kothler and Armstrong, 1995: 246).

\section{Perception}

There are several notions of perception. According to the Ministry of National Education (2001: 259), perception is a response or finding a direct picture of a finding or a direct picture of an absorption of someone in knowing things through the five senses. In this sense it is clear, that perception is the impression of an image or response that a person has after that person absorbs to know some things (objects), through the five senses. 
According to Bimo Walgito (1990: 54), perception is an impression of an object that is obtained through the process of sensing, organizing, and interpreting the object that is accepted by the individual, so it is a meaningful and integrated activity in the individual. This opinion is not contrary to the previous opinion, but rather explains the process of occurrence, that is, after absorption, the images obtained through the five senses are then organized, then interpreted, so that they have meaning or meaning for the individual, while the process of perception occurs is an unity of activity in the individual.

The third understanding put forward by Robbins (2003: 97) which describes that perception is an impression obtained by individuals through the five senses then analysed (organized), interpreted and then evaluated, so that individuals get meaning. Robbins' opinion is more refined by previous opinions, namely the existence of elements of evaluation or assessment of the object of perception.

\section{Hypothesis}

The hypothesis can be interpreted as a temporary answer to the research problem, until proven through the collected data. The above definition can be concluded that the hypothesis is a temporary answer that must be done truthfully.

Based on the theory, literature review as well as the mindset above, the hypotheses of this study are:

$\mathrm{H}_{1} \quad$ : There is a significant influence between perceptions on the attitudes of entrepreneurs and employees

$\mathrm{H}_{2}$ : There is a significant influence between perceptions and attitudes towards the behaviour of entrepreneurs and employees

\section{Definition of Variable Operations}

The operational definitions and measurements used in this study, such as the measurement of the variables used can be explained as follows: a. Exogenous variables

Exogenous Variables: These variables are often referred to as independent variables. The independent variable is a variable that influences or is the cause of changes or the emergence of endogenous variables. In this research, the exogenous variable is perception (X) Perception according to Bimo Walgito (1990: 54), perception is an impression of an object obtained through the process of sensing, organizing, and interpreting the object which is accepted by individuals, so it is a which means and is an integrated activity in individuals.

b. Intervening Variable

Intervening variables in this study are Attitude, (Z), Attitude. According to (Kothler and Armstrong, 1995: 246), attitude is the evaluation, feelings and tendencies of someone who is relatively consistent with an object or idea. Attitude puts a person into a mind like or not educate something, move toward or away from something.

c. Endogenous variables

Endogenous variables: often referred to as dependent variables. Dependent variable is a variable that is affected or which is due, because of the independent variable. Endogenous variables in this study are behavior $(\mathrm{Y})$. Endogenous variables in this study behaviour. Behaviour according to Prasetijo and Ihalauw (2005: 8) is consumer behavior can be interpreted as a study of how decision makers (decision units), both individuals, groups, or organizations, make a buying decision or make a purchase transaction for a product and consume it.

\section{Population and Sample}

Population is the total number of research subjects. The population in this study is the entire subject of research, namely customers of Bank Syariah namely: BNI Syariah, Bank Mandiri 
Syariah, Bank Muamalat in Medan. In this study the population number is unclear or uncertain, the number of its members is not known with certainty, therefore it is not possible to take a sample from that population fairly. Then these sampling techniques from infinite and unclear populations are grouped into nonprobability sampling families, which are ways of taking samples that do not give equal opportunity to each member to be sampled, or non-random sampling (non-random sampling methods).

So that the nonprobability (nonrandom) sampling technique that is suitable is Quota sampling. Quota sampling technique is a sampling technique by setting a certain amount as a target that must be met in the sampling of the population (especially infinite or unclear), then by benchmarking the number the researcher takes the sample arbitrarily as long as it meets the requirements as a sample of that population. In the sampling quota the number of samples determined is only an estimate that will be relatively adequate to obtain the necessary data that is expected to reflect the population, cannot be calculated explicitly the proportion of the population, because the number of population members is not known with certainty earlier. For this reason, quota sampling is, therefore, non-random sampling.

Quota sampling According to Sugiyono (2001: 60) states that quota sampling is a technique for determining samples of populations that have certain characteristics to the desired amount (quota). According to Margono (2004: 127) in this technique the population is not counted but is classified into several groups. Samples are taken by giving a certain quorum or quorum to the group. Data collection is carried out directly on the sampling unit.

Related to Requirements Samples must have all the criteria of the population because consideration of sampling must have two criteria namely:

1. The precision of the sample is the consideration of the estimates that might arise in taking data caused by the sample.

2. The accuracy refers to the nature and character of the sample used.

Then this study determines the criteria for the sample to be taken namely:

1. Active Customers

2. Customer is an employee or entrepreneur

3. The customer has been a customer of the Bank for a minimum of 6 months

4. Customers who use savings bank products / services or deposits

The desired sample size is 150 respondents, because there are 3 Islamic banks, 50 questionnaires have been distributed to each bank.

\section{Methode of Collecting Data}

The method used in collecting this data is a questionnaire, which is a detailed and complete list of questions regarding the information needed in the research filled out by respondents. Respondents in this study were entrepreneurs and employees.

\section{RESULT and DISCUSSION}

The population in this study is the entire subject of the study, namely customers of Bank Syariah namely Bank BNI Syariah, Bank Mandiri Syariah, Bank Muamalat in Medan. As stated earlier that given the population size is not known with certainty, due to information and other limitations, the appropriate sampling is Quota sampling. And based on predetermined criteria, this study has determined the criteria for the sample to be taken, namely:

1. Active Customers

2. Customer is an employee or entrepreneur

3. The customer has been a customer of the Bank for a minimum of 6 months

4. Customers who use Savings bank products / services or deposits 
After distributing 150 respondents to 3 Bank Syariah, finally 109 questionnaires were collected, this was due to the character of the customers who were generally uncomfortable to be bothered with the questionnaire sheets provided. Characteristics of respondents can help obtain a picture of the behavioural trends of the selected respondents in the study. Characteristics of respondents are grouped based on gender, age, level of education, length of time being a customer, and employment in this case is the status of the employee or entrepreneur customer who is only the target of this study.

\section{Hypothesis Testing}

The results of research in the influence of perception and attitude towards the customer behaviour in using sharia banking financial services in Medan can be identified by using path analysis to analyze the influence of variables either directly or indirectly through mediator variables (intervening).

To find out whether or not there is a direct influence between exogenous variables on intervening and interving variables on endogenous, as well as indirect effects of exogenous variables on endogenous through intervening, a path analysis test using SPSS 20, namely the hypothesis criteria (Ha) is accepted if Sig $<0.05$ for direct effects both simultaneously (F-calculated value) and partial, coupled with seeing the value of $t$ to see the partial effect of $t$-count $>t$-table.

The following are the results of the path analysis test through:

\section{Model $1: \mathrm{Z}=\mathrm{a}+\mathrm{b} 1 \mathrm{X}+\mathrm{e} 1$}

a. Determination Test ; Based on the table appears that the coefficient of determination or R Square (R2) of 0.597 means that $59.7 \%$ of the attitude variable can be explained by the perception variable in Bank Syariah. So the error $(\varepsilon)=$ $1-\mathrm{R} 2=1-0.597=0.403$. It means that around $40.3 \%$ is influenced by other variables outside the research model. In other words, the attitude variable that can be explained by using the perception variable is $59.7 \%$.

b. Partial Test ; Test Results Analysis of the Path of Perception Variables to Attitudes. Based on the table, it can be seen that the significance value for the Perception variable is 0,000 and the standardized coefficient is 0.772 . Because the significance value is smaller 0,000 $<0.05$, it can be concluded that the Perception variable has a significant effect on the Attitude variable.

Based on the test above we get the multiple regression analysis model as follows:

$$
\mathrm{Y}=6.64+1.12 \mathrm{X}
$$

The above model can be interpreted that:

1. If the other variables are fixed, then the Attitude variable will also increase.

2. If the Perception variable increases and the other variables remain constant, the Attitude variable will also increase. Conversely, if the Perception variable decreases and other variables remain, then the Attitude variable will also decrease. Perception variable and attitude variable have a positive relationship.

Next is looking at the effect of the perception variables on attitudes towards behavior, which are presented in the model and table:

2. Model $2: \mathrm{Y}=\mathrm{a}+\mathrm{b} 1 \mathrm{X}+\mathrm{b} 2 \mathrm{Z}+\mathrm{e}$

a. Determination Test ; In the table appears that the coefficient of determination (R2) of 0.814 means that $81.4 \%$ of Behavioral variables can be explained by the variables of Perception and Attitude in Bank Syariah. So the error $(\varepsilon)=1-\mathrm{R} 2=1-0.814=0.186$. It means that around $18.6 \%$ is influenced by other variables outside the research model.

b. Simultaneous Test ; Based on the table above it can be seen that the calculated $\mathrm{F}$ value of 232.031 with a significance value of 0,000 . Because the significance value is smaller $0.0000<0.05$, it can be concluded 
that the variables of perception and attitude simultaneously (together) affect the Behavior variable.

c. Partial Test ; Test Results of Perception Variable Path Analysis, Attitudes Towards Behaviour Based on the results above it can be seen that:

a. The significance value for the Perception variable is 0.021 and the standardized coefficient is 0.154 . Because the significance value is smaller $0.021<0.05$, it can be concluded that the Perception variable has a significant effect on the Behavior variable.

b. The significance value for the Attitude variable is 0,000 and the standardized coefficient is 0.778 . Because the significance value is smaller $0,000<0.05$, it can be concluded that the Attitude variable has a significant effect on the Behavior variable.

Based on the test we get the multiple regression analysis model as follows:

$\mathrm{Y}=2.708+0.715 \mathrm{X}+0.618 \mathrm{Z}$

Interpreted as follows:

a. If the perception and attitude variables are fixed, then the behavior variable will increase.

b. If the perception variable increases and the attitude variable remains, then the Behavior variable will increase. Conversely, if the Perception variable decreases and the attitude variable remains, then the Behavior variable will decrease. Perception variable and behavior variable have a positive relationship.

c. If the attitude variable increases and the perception variable is fixed, then the behavior variable will increase. Conversely, if the Attitude variable decreases and the perception variable is fixed, then the Behavior variable will decrease. Attitude variables and behavior variables have a positive relationship.

\section{Path Analysis}

This is the results of the SPSS output on the two regression equation models

a. Model indirect effect (indirect effect):

$$
\mathrm{Z}=\rho \mathrm{xz} \mathrm{X}+\varepsilon 1
$$

In this indirect effect model, the residual coefficient is: $\varepsilon 1=: \varepsilon 1=\sqrt{1-\mathrm{R} 1^{2}}$

$$
\varepsilon 1=\sqrt{1-0,597}=0.403
$$

then the indirect effect model is obtained as follows:

$$
Z=0.772 X+0.403
$$

b. Direct effect model (direct effect):

$$
Y=\rho x y X+p z y Z+\varepsilon 2
$$

In this direct effect model, the residual coefficient is: $\varepsilon 2=\sqrt{1-\mathrm{R}^{2}}$

$\varepsilon 2=\sqrt{1-0,814}=0.186$

then the indirect effect model is obtained as follows:

$$
Y=0.1541 X+0.7779 Z+0.186
$$

So that the path analysis picture is as follows:

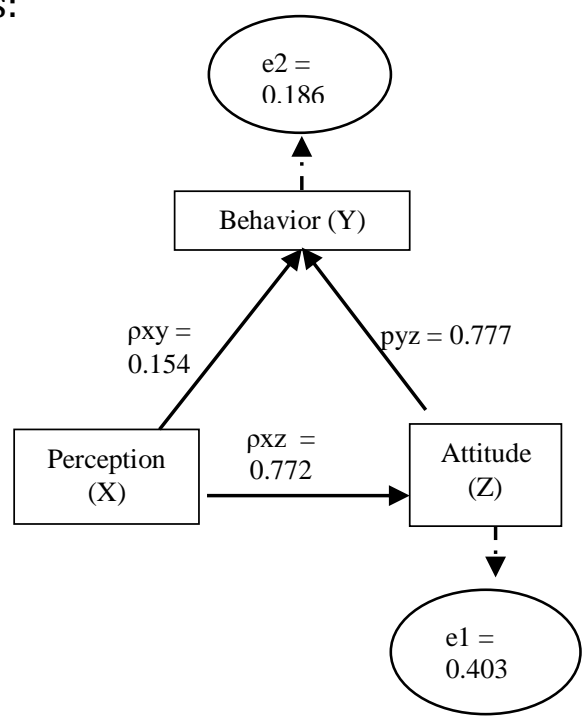

From the picture above, we can determine the coefficient of direct effect, indirect effect and total effect as follows:

1. Direct influence

The direct effect is the direct effect of the variable $\mathrm{X}$ on $\mathrm{Y}$ and the variable $\mathrm{Z}$ on $\mathrm{Y}$, can be simply presented as follows:

- Effect of $X$ on $Y(X=>Y)$ or pxy = 0.772 
- $\quad$ Effect of $Z$ on $Y(Z=>Y)$ or pyz $=$ 0.778

2. Indirect Influence

The indirect effect of exogenous variables on endogenous variables through variable

\begin{tabular}{|l|l|l|l|}
\hline $\begin{array}{l}\text { Indirect } \\
\text { Effect }\end{array}$ & $\begin{array}{l}\text { statistic } \\
\text { test } \\
\text { (Sobel } \\
\text { test) }\end{array}$ & std error & $\begin{array}{l}\mathrm{p} \text { - } \\
\text { value }\end{array}$ \\
\hline & & & \\
\hline $\begin{array}{l}\mathrm{X} \mathrm{to} \mathrm{Y} \\
\text { through Z }\end{array}$ & $\begin{array}{l}7.552145 \\
08\end{array}$ & $\begin{array}{l}0.079521 \\
33\end{array}$ & $\begin{array}{l}0.000 \\
0\end{array}$ \\
\hline
\end{tabular}

Z, includes:

The indirect effect of $\mathrm{X}$ on $\mathrm{Y}$ through $\mathrm{Z}$ (X $=>\mathrm{Z}=>\mathrm{Y}$ ) is the product of the path coefficients pxz and pyz $=0.772 \times 0.78=$ 0.6

\section{Total Influence}

The total effect is the sum between the direct effect and the indirect effect, as follows:

The effect of the total variable $\mathrm{X}$ on $\mathrm{Y}=\mathrm{pxy}$ $+(p x z)(p z y)=0.1541+(0.772 \times 0.78)=$ 0.7546

c. Test of Significance of Indirect Effects

$$
z=\frac{a x b}{\sqrt{b^{2} x s_{a}^{2}+a^{2} x s_{b}{ }^{2}+s_{a}^{2} x{s_{b}}^{2}}}
$$

To find out the significance of the indirect effect, the z-statistical formula is used developed by Sobel as follows:

Where :

a, b and c are path coefficient values $\mathrm{sa}$ and $\mathrm{sb}$ are the standard errors for $\mathrm{a}$ and b. In this case, the basis for decision making is to compare t-tables with $\mathrm{z}$ count. The data above is known $\mathrm{dk}$ (degrees of freedom) $=109-2=35$ with a level of confidence $\alpha=0.05$ then the $t$ table of, assessment criteria:

1. If the $\mathrm{z}$-count $>\mathrm{t}$-table, the indirect effect is significant. This means that the influence of the exerect effect of exogenous variables on endogenous variables through moderating (intervening) variables significantly or significantly.
2. If the $\mathrm{z}$-count is <t-table, the indirect effect is not significant. This means that there is no inderect effect of exogenous variables on endogenous variables through moderating (intervening) variables.

Based on the previous summary table, it can be seen that:

The indirect effect of $\mathrm{X}$ on $\mathrm{Y}$ through $\mathrm{Z}$ (X $=>Z=>Y$ ), Sobel test:

$=\frac{0.772 \times 0.778}{\sqrt{(0.778)^{2} \times(0.088)^{2}+(0.772)^{2} \times(0.0524)^{2}+(0.778)^{2} \times(0.772)^{2}}}$

So that it is obtained that $\mathrm{z}$ is greater than t-table or $7.552>1.96$, it can be concluded that there is an indirect effect of perception of behavior through attitude significantly with a confidence level of $95 \%$ or an error rate of $5 \%$. Sobel test can also be calculated using the Sobel test calculator

http://quantpsy.org/sobel/sobel.htm, and the results are simplified with the following results:

It can be seen that the p-value for indirect effect is significant. This means that the Attitude variable can mediate the relationship between the Perception and Behavior variables.

\section{CONCLUSION AND SUGGESTION}

From the results of the research above, it can be concluded that:

1. Exogenous variables of perception have a significant effect on attitude variables.

2. Intervening attitude variables can be explained by the exogenous variables of Perception of 59.7\%, and $40.3 \%$ are influenced by other variables.

3. That $81.4 \%$ of Behavior variables can be explained by the exogenous variables of Perception and Interventing Attitude variables in Islamic banks, meaning that around $18.6 \%$ are influenced by other variables outside the research model. 
4. Variable perceptions and attitudes simultaneously (together) affect the Behavior variable.

5. Partially, Perception variable has a significant effect on Behavior variable and Attitude variable has a significant effect on Behavior variable.

6. See the results of the table above that there is an indirect effect of perception of behavior through attitude so that attitude is assumed to be an intervening variable.

7. The coefficient of direct influence and indirect effect is as follows.

a. The direct effect is the direct effect of the variable $\mathrm{X}$ on $\mathrm{Y}$ and the variable $\mathrm{Z}$ with respect to $\mathrm{Y}$, can be simply presented as follows:

- Effect of $X$ on $Y(X=>Y)$ or pxy = 0.772

- $\quad$ Effect of $\mathrm{Z}$ on $\mathrm{Y}(\mathrm{Z}=>\mathrm{Y})$ or pyz = 0.778

b. Indirect Effect

The indirect effect of exogenous variables on endogenous variables through the variable $Z$, includes: the indirect effect of $X$ on $Y$ through $\mathrm{Z}(\mathrm{X}=>\mathrm{Z}=>\mathrm{Y})$ is the product of path coefficients pxz and pyz $=0.772 \mathrm{x}$ $0.78=0.6$

So it can be seen that the direct influence between the perception variable or $\mathrm{X}$ on the behavior variable $(\mathrm{Y})$ has a lower effect, compared to the indirect effect between the perception variable $(\mathrm{x})$ on the behavior (y) through the attitude variable (z)

\section{Suggestions}

1. Bank Syariah in Medan should have provided more targeted socialization to prospective customers, bearing in mind that young people and highly educated people are generally more interested in Islamic banks than parents, this is due to several things including; it's easy for young people to get the latest information compared to parents. Young people are more receptive to new things than parents and so forth. So that more young people use Bank Syariah services in Medan.

2. Because generally Bank Syariah customers are quite loyal, it should be better thought about how to retain existing customers, so as not to move to another bank. Providing financial consulting or providing other facilities that benefit potential customers as well.

3. It is expected that other researchers examine other variables that have not been examined in this study.

\section{REFERENCES}

Ahmadi, Abu. 2002. Psikologi Sosial.(Jakarta: Rineka Cipta)

Antonio dan Muhammad Syafi'i, 2001. Bank Syariah dari Teori ke Praktik, (Jakarta : Gema Insani)

Bryant J, Zillmann D, 2002. Media Effects: Advances in Theory and Research. Ed.ke-2.(London (GB): LEA)

Kotler phillip dan keller kevin lane, 2008. Manajemen Pemasaran edisi 13, (Jakarta : elangga)

Kotler, Philip, 1999. The Consumer Behavior in Marketing Management. (Published by Simon \& Schuster Pte.Ltd)

$$
\begin{array}{ccc}
\text { Notoatmodjo, } & \text { Soekidjo, } & 2003 . \\
\text { Pengembangan } & \text { Sumber } & \text { Daya } \\
\text { Manusia, (Jakarta } & \text { PT. Rineka Cipta) }
\end{array}
$$

Prasetijo, Ristiyanti dan John J.O.I. Ihalauw. 2005. Perilaku Konsumen. Andy(Yogyakarta:Andi.Offset)

Robbins, Stephen P, 2003. Perilaku Organisasi. (Jakarta : Index) 
Setiadi Nugroho J, 2003 Perilaku konsumen, (Jakarta:Prenada Media)

Sugiyono, 2001. Metode Penelitian, (Bandung: CV Alfa Beta)

Sugiyono, 2003. Metode Penelitian, (Bandung: CV Alfa Beta)

Supino, P. G., \& Borer, J. S, 2012. Principles Research Methodology: A Guide for Clinical Investigators. (New York: Springer)

Walgito, Bimo, 1990. Pengantar Psikologi Umum. (Yogyakarta: Andi Offset) 